\title{
Current Research: Current Research in the Upper McGee Creek Drainage, Oklahoma
}

James Briscoe Briscoe Archaeology

Follow this and additional works at: https://scholarworks.sfasu.edu/ita

Part of the American Material Culture Commons, Archaeological Anthropology Commons, Environmental Studies Commons, Other American Studies Commons, Other Arts and Humanities Commons, Other History of Art, Architecture, and Archaeology Commons, and the United States History Commons

Tell us how this article helped you.

This Article is brought to you for free and open access by the Center for Regional Heritage Research at SFA ScholarWorks. It has been accepted for inclusion in Index of Texas Archaeology: Open Access Gray Literature from the Lone Star State by an authorized editor of SFA ScholarWorks. For more information, please contact cdsscholarworks@sfasu.edu. 


\section{Current Research: Current Research in the Upper McGee Creek Drainage, Oklahoma}

\section{Creative Commons License}

\section{(c) (1) \&}

This work is licensed under a Creative Commons Attribution-NonCommercial 4.0 International License 


\title{
Current Research: Current Research in the Upper McGee Creek Drainage, Oklahoma
}

\author{
James Briscoe \\ Briscoe Archeology
}

In recent years the Choctaw Nation has acquired a roughly 80 square mile ranch in the western edge of the Winding Stair Mountains of southeastern Oklahoma (Figure 1). The land is currently a working ranch and timber management area. Choctaw Forestry manages timber activities and range management with the intention of returning the land to an oak savanna setting. Active logging of pine and selected hardwoods and ongoing controlled surface burns are included in Forestry activity on the ranch. The project is supported by the Choctaw Nation Historic Preservation Department, which is responsible for the inventory and protection of the cultural resources found on the property.

Archeological surveys were conducted in the McGee Creek Reservoir area in the 1970s and 1980s (McGuff 1980; Perttula and McGuff 1993) and a wide range of significant cultural resources were located in the reservoir area, less than 10 miles south of the ranch. Only one previous survey was conducted on the ranch property, by the Oklahoma Conservation Commission in the 1980s (Brosowske and Vehik 1999) ahead of construction of an upland flood control reservoir. Significant archeological resources were recorded. Since very little was known about the ranch property itself, it was presumed that this portion of the McGee Creek drainage would also have a similar archeological importance.

The ranch is primarily mountainous with steep ridges, narrow to wide bench terraces (Figure 2), and generally flat and narrow floodplains along McGee Creek on the southern half and Brushy and Peaceable Creeks along the northern edge of the property. At the present time, archeological investigations have been confined to Atoka and Pittsburg Counties, Oklahoma. Approximately half of the land is heavily timbered and half is brushy pasture. Extensive outcrops of chert gravels are found throughout the area, both on slopes and along drainages. Briscoe Archeology is also

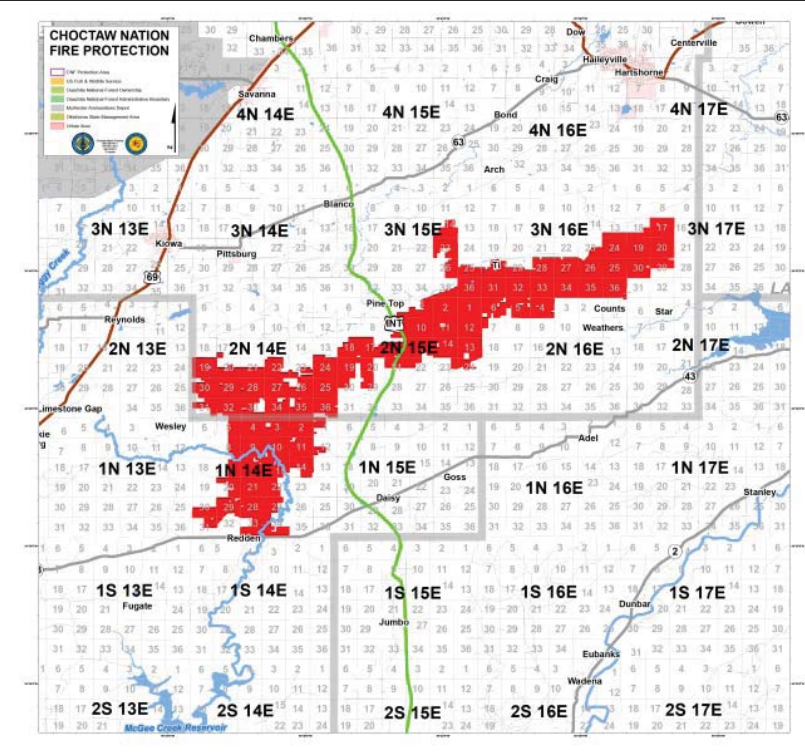

Figure 1. The Winding Stair Property. Daisy Ranch (current study area) has been designated for the portion west of the Indian Nations Turnpike (green line). Ti Valley Ranch has been designated for the portion east of the turnpike.

working with the Oklahoma Geological Survey to map and identify important lithic resources in the area.

Briscoe Archeology was contracted to begin large scale surveys on the property in 2015. So far approximately 14,000 acres have been covered (Briscoe 2015, 2016a-2016d, 2017a-b). Special attention is being placed on a $60 \mathrm{~m}$-wide corridor along proposed fire fuel breaks and fence lines. Interior areas are covered by surface reconnaissance along transects of about 20-30 m intervals, walked in an ambling zigzag pattern. Around 400 archeological sites have been recorded so far.

Prehistoric sites ranging from Paleoindian through the Woodland Fourche Maline periods are common, with Fourche Maline black earth middens prevalent along major and minor stream terraces. Several large midden mounds were located along McGee Creek, suggesting that a large population occupied the area during the latter portion of the Late Archaic and possibly Early Woodland periods. Smaller encampments and activity areas are generally located 


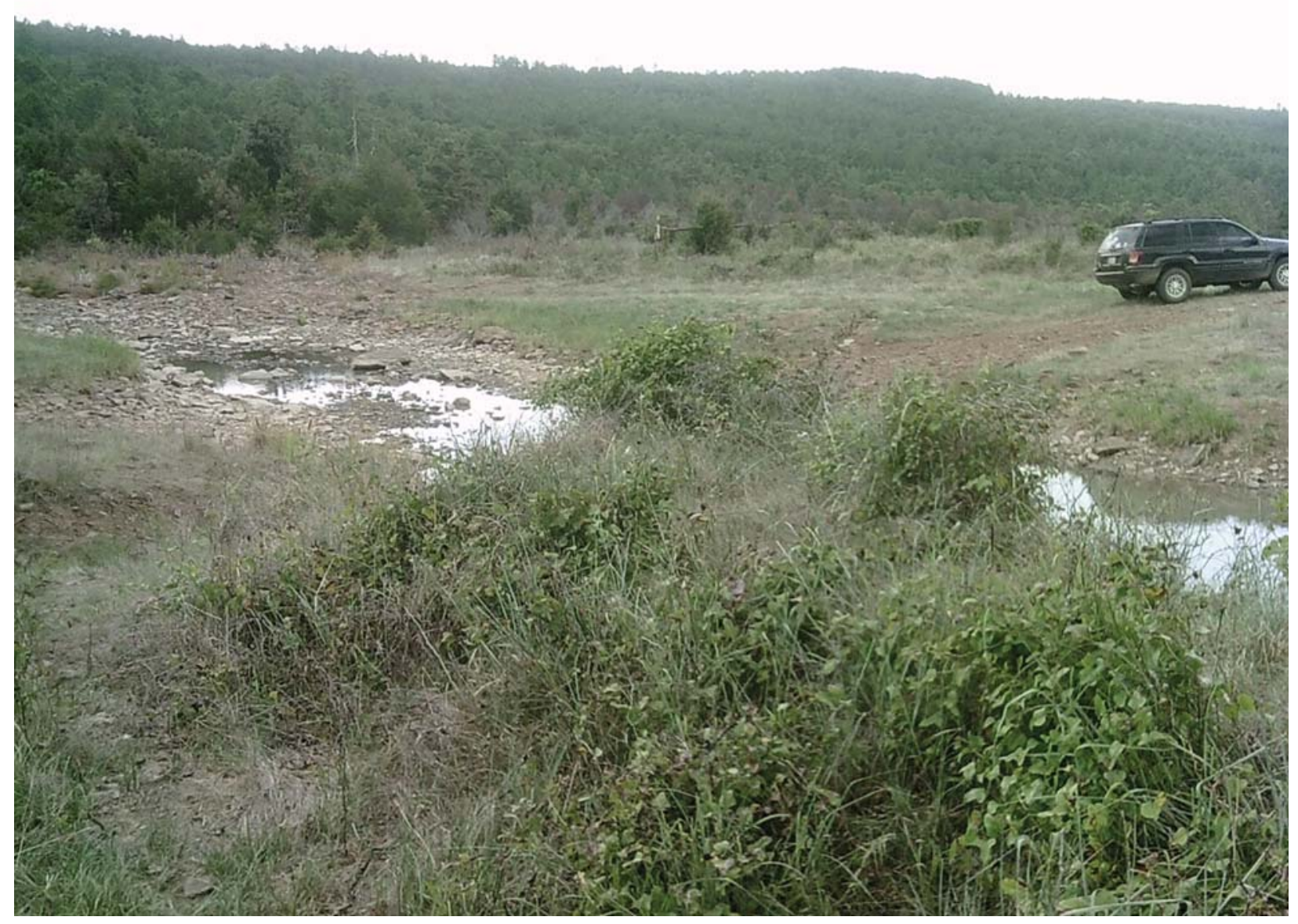

Figure 2. Typical mountain scenery of a feeder stream in the McGee Creek drainage.

on or near lithic resource areas and seasonal springs throughout the mountains (including ridge tops and ridge line benches). A basic pattern of substantial prehistoric camps/villages located along streams or along the ridgetops, surrounded by smaller camps or activity areas, has been observed.

Thus far, however, no Caddo era sites or artifacts have been recorded during the survey. The absence of evidence for Caddo occupations in this portion of the mountainous uplands may relate to the nature of a surface survey (intensive shovel testing was not performed due to a lack of soils and extremely rocky conditions), but is more probably an indication that areas this far from arable bottom lands were seldom visited or used by Caddo peoples. A similar conclusion was reached by Perttula and McGuff (1985, 1993:114) for the McGee Reservoir area, where only temporarily occupied Caddo localities were found.

\section{References Cited}

Briscoe, James

2015 Cultural Resources Report on Fire Fuel Break Lanes on the Winding Stair Ranch Property, Atoka County, Oklahoma. Briscoe Archeology Contract Report, Norman.

2016a Archeological Area-Wide Survey of the Redden Tract, Choctaw Nation Winding Stair Ranch, Atoka County, Oklahoma. Briscoe Archeology Contract Report, Norman.

2016b Archeological Survey of the Bald Mountain Tract, Choctaw Nation Winding Stair Ranch, Atoka County, Oklahoma. Briscoe Archeology Contract Report, Norman. 
2016c Archeological Survey of Fire Fuel Breaks on the Jerry Lambert Tract on the Choctaw Nation Winding Stair West Ranch, Atoka County, Oklahoma. Briscoe Archeology Contract Report, Norman

2016d Archeological Survey of the Bar Diamond Tract, Choctaw Nation Winding Stair West Ranch, Pittsburg and Atoka Counties, Oklahoma. Briscoe Archeology Contract Report, Norman.

2017a Archeological Survey Report on the Wagon Wheel West Tract, Choctaw Nation Winding Stair Ranch, Pittsburg County, Oklahoma. Briscoe Archeology Contract Report, Norman.

2017b Archeological Survey of the Well Pad Tract, Choctaw Nation Daisy Ranch, Pittsburg County, Oklahoma. Briscoe Archeology Contract Report, Norman.
Brosowske, Scott and Rain Vehik

1999 Phase I and II Investigations at Impoundments 14 and 15A, Brushy-Peaceable Watershed, Pittsburg County, Oklahoma. Archaeological Research Report No. 17. Oklahoma Conservation Commission, Oklahoma City.

McGuff, Paul

1980 Cultural Resource Survey and Testing at the McGee Creek Project, Oklahoma. Environmental Assessments, Inc., Pauls Valley, Oklahoma.

Perttula, Timothy K. and Paul McGuff

1985 Woodland and Caddoan Settlement in the McGee Creek Drainage, Southeast Oklahoma. Plains Anthropologist 30 (109):219-236.

1993 A Cultural Resources Survey of the McGee Creek Project Area, Atoka County, Oklahoma. McGee Creek Archaeological Reports, Vol. I. University of North Texas Institute of Applied Sciences, Denton. 